International Journal of Social Sciences and Humanities
Available online at http://sciencescholar.us/journal/index.php/ijssh
Vol. 2 No. 1, April 2018, pages: $92 \sim 104$
e-ISSN: 2550-7001, p-ISSN: 2550-701X
http://dx.doi.org/10.29332/ijssh.v2n1.96

\title{
Maintaining Social Relationship of Balinese and Sasak Ethnic Community
}

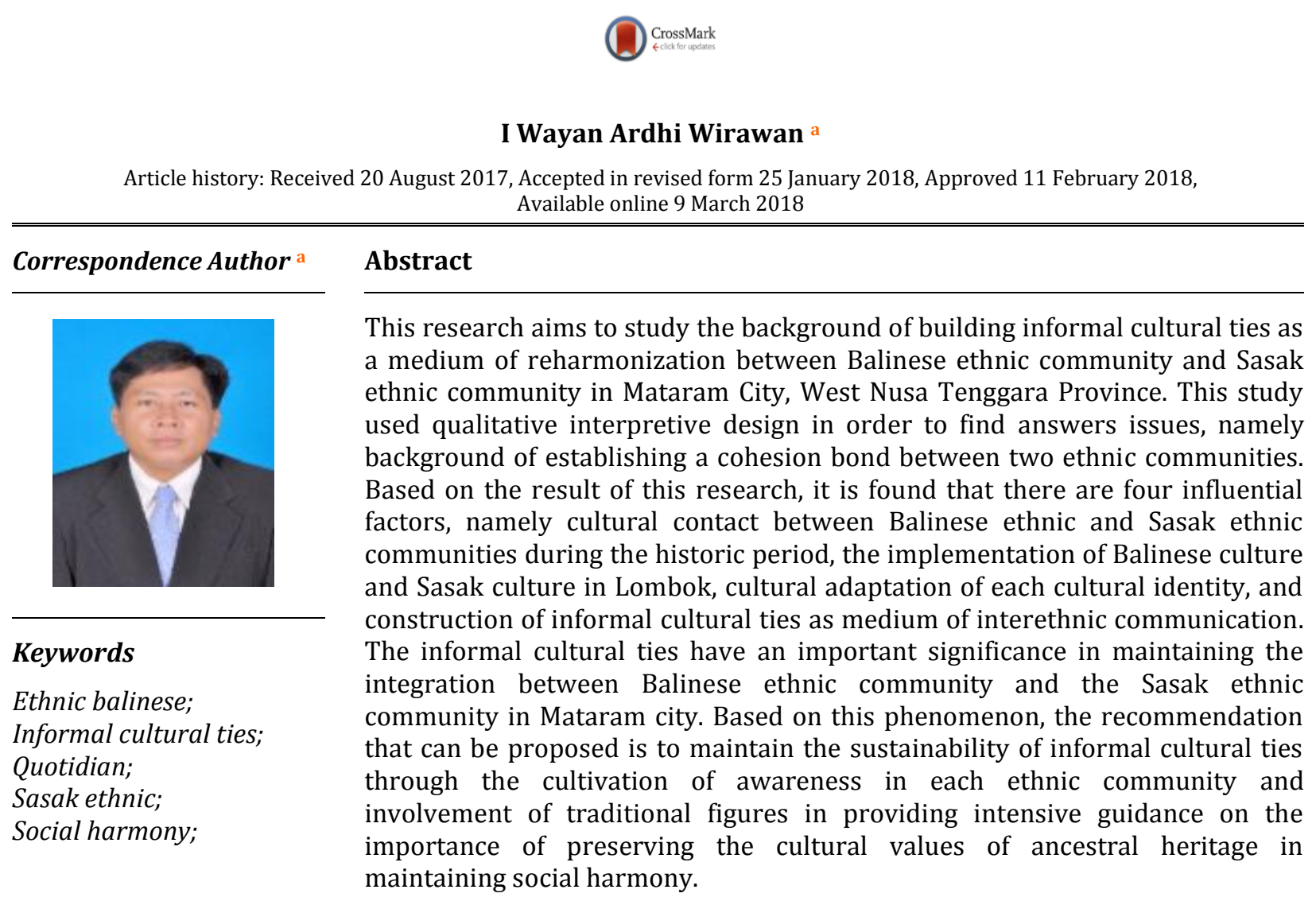

e-ISSN : 2550-7001, p-ISSN : 2550-701X ๑Copyright 2018. The Author. SS Journals Published by Universidad Técnica de Manabí. This is an open-access article under the CC BY-SA 4.0 license

\section{Contents}

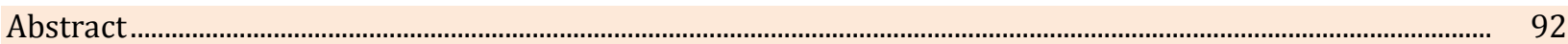

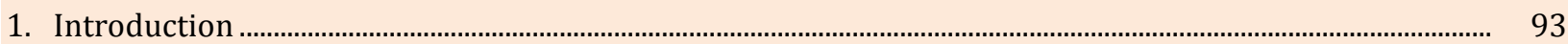

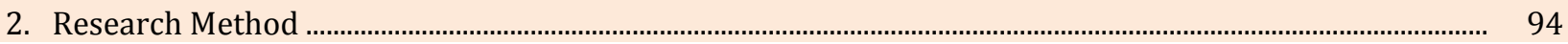

a Lecturer at Mataram State Hindu College of Gde Pudja, Indonesia 
3. Results and Analysis

3.1 Contact Between Bali-Hindu and Sasak-Islam Intercommunity in Lombok

3.2 Implementation of Balinese Culture and Sasak Culture in Lombok of the Historical Era ....

3.3 Construction of the Informal Cultural Ties Among Societies of Bali-Hindu and Sasak-Moslem.

4. Conclusion.

Acknowledgements

References.

\section{Introduction}

Local wisdom in the form of informal cultural ties between Balinese ethnic community and Sasak ethnic community in Mataram city diachronically involves a number of supporting data, in particular, linked to the historical aspect. With regard to that, the establishment of informal cultural ties is inseparable from the contacts that occurred at the beginning of Balinese ethnic community Hindu encounter with the Sasak ethnic community that is Muslim. Contacts that occur between the two ethnic communities that different religions to build communication and interaction in the face of life issues concerning social aspects, the implementation of religious practices, and culture, others. In the social aspects of communication and interaction that occur include activities related to mutual cooperation, such as in building places of settlement, making facilities and improvements in the quality of life together, helping each other in overcoming natural disasters, and others. The social relations that occur between the two ethnic groups are associated with Koentjaraningrat concept (2004: 53-54) as a form of mentality that has been controlled by the norms that have been rooted in the culture of Indonesian society.

In the field of religious practice between Balinese people who embraced Hindu and Sasak people who embraced Islam since the historical time has built communication and interaction. The phenomenon is indicated by awakening awareness to keep each other's harmony of each religious practices. One thing that is very interesting in the implementation of religious practice when the implementation of religious festivals conducted by Hindus, those who are Muslims participate feels the atmosphere of joy. The execution of the religious festivals Hindu in Lombok, such as galungan, kuningan, and other religious festivals, their relatives who embraced Islam joined the congratulations of the holiday. Likewise, when Muslims perform religious holidays, such as idul fitri, maulid, and others, their Hindu relatives also enliven religious festivals. Communication and interaction that occurs in the implementation of the religion of each religious follower are also often accompanied by a visit to the homes of people who carry out religious holidays to conduct a silaturahmi in the terminology of Islam or do the simakrama used by the terms of Hindus. These forms of communication and interaction can dilute the barriers of difference between them in order to build social bonds.

The interaction and communication that occurs in the cultural field concern the implementation of the culture owned by each ethnic community. The ethnic community of Bali in its historical time when contact with the Sasak ethnic community in Lombok has made cultural contact. The Balinese who come to Lombok bring the Balinese cultural system and implement the cultural system in their new settlement. Likewise, the Sasak people as natives of Lombok Island also have a cultural system that is implemented as a legacy of their ancestors. Both cultural systems are in contact with ethnic groups that become agents and build cultural adaptation on a number of elements. Such cultural adaptation as an exchange event of cultural elements that can improve the quality of cultural implementation of each ethnic group.

In the implementation of cultural systems that are actualized by Hindus and Muslims in Mataram since the historic time is also closely related to the implementation of the religious practice. Cultural practices related to the practice of religion, as seen in the activities of religious holidays. In the execution of religious festivals since the historic period has built the tradition of ngejot, which gives something as a mark of respect to different religious followers in enlivening religious holidays. With regard to that, in the execution of the religious festival of Hinduism the tradition of $n g$ ejot is done by giving treats of food, drink, or other forms of threats to their relatives who are Muslim who embrace Islam. The same thing happens when Muslims carry out religious holidays to give food, drink, or other treats to their relatives who embrace Hinduism. The mutual-minded tradition has been rooted in the Balinese-Hindu and Sasak-Islam

Wirawan, I. (2018). Maintaining Social Relationship of Balinese and Sasak Ethnic Community. International Journal Of Social Sciences And Humanities (IJSSH), 2(1), 92-104. doi:10.29332/ijssh.v2n1.96 
Society from one generation to the next that continues today. This mutual adventure becomes an informal communication medium between Hindus and Moslems.

Synergize with the above events, in the implementation of the cultural system between Balinese-Hindu ethnic group with Sasak-Islam ethnic group also actualize tradition of saling undang. Among the people of Sasak ethnic the tradition of saling undang is termed by the tradition of pesilak. Implementation of this tradition is to invite other ethnic groups, either individually or in groups on religious activities or cultural activities. Those invited to an activity basically help in working on the work done by those who have a celebration. The event builds fraternal ties between Hindu Balinese Hindus and Sasak Moslems.

The activity of visiting each other when one ethnic group has died is also categorized as a cultural activity related to the implementation of the religious practice. The tradition of visitation is known as majenukan. Those who are present in the tradition of majenukan as a sign of sorrow. Different religions attending these activities are at once a sign of having a fraternal bond. This tradition also contains positive energy in building awareness for mutual respect among different ethnic groups of religions. Such awareness on its accumulation can manifest attitudes of tolerance to the differences that exist in a social space.

Cultural activities that can build informal ties between the Balinese-Hindu community and the SasakIslam community in the form of ngejot tradition, the tradition of saling undang, and the majenukan tradition that has been initiated since the historic times are very positive for realizing social harmony in a society with a relatively high plurality level, as in Mataram City. These traditions are associated with the terms conveyed by Varshney (2002: 50-51) as a bond of the quotidian or daily bond. These ties are informal unofficial ties that are capable of maintaining social harmony in the villages, but inadequate in cities. The concept proposed by Varshney is associated with events occurring in the city of Mataram in order to maintain the informal cultural ties as a medium of strengthening the emotional bond between the Balinese community with Sasak in realizing social harmony.

Based on the above explanation, it is necessary to strengthen the informal cultural ties as a vehicle to maintain social relations between the Balinese-Hindu community and the Sasak-Moslem community in Mataram City. This is based on the fact that in the implementation of cultural practices undertaken by each ethnic community has built a social awareness for mutual respect for differences. Under these conditions, the differences that exist between them are recognized and accepted as part of a common life to build social harmony. Cultural traditions shared by each ethnic group tend to fade, especially with the influx of modernization. Social ties are likely to crack if there is no preventive action to save the noble traditions of the past heritage.

\section{Research Method}

Research related to conducting background study on cultural awakening informal cultural ties between Balinese ethnic community and Sasak ethnic community in Mataram City, West Nusa Tenggara using the qualitative interpretative method. In the scope of this study, the study used case study techniques. The main reason for the use of case studies refers to Yin (2004:4) that case studies provide an opportunity for researchers to maintain the holistic and meaningful characteristics of real-life events. This research is designed in the form of descriptive interpretative. Related to that, in taking field data accompanied by interpretation during the conduct of research activities.

This study uses two types of data sources, namely primary and secondary. Primary data were obtained directly in the field, especially based on observations and interviews with a number of informants. Meanwhile, secondary data sources are obtained indirectly from key data sources, but through document sources, such as archives, statistical reporting data, monographs, and others. The use of secondary data sources is very important to obtain data that escape the observations of researchers and informants

This research uses three data collection techniques, namely observation, interview and document study. Observations conducted by researchers by way of observation of the object under study and at the same time do the recording. Interviews were conducted using non-structured interview techniques as recommended by Fontana and Frey (2009: 507) that non-structured interviews provide more space than other types of interviews. This study uses document studies in order to obtain secondary data.

Informant determination technique used as a data source in this research use the purposive technique. This technique is done by first determining the informant will be used as a data source by meeting a 
number of requirements. Firstly, prospective informants are residents who live in the area of Mataram City. Secondly, it has extensive knowledge of traditional cultural practices, the implementation of local traditions, and insights on social, cultural and religious activities in Mataram. Thirdly, candidate informants play an active role in various activities related to traditional cultural practices, forwarding local traditions, and the implementation of adat in the region of Mataram. Fourthly, being open to convey the knowledge especially with regard to the focus of this research.

Presentation and analysis of data in this research in the form of qualitative data in the form of expressions, words, opinions, and opinions obtained directly in the field. Qualitative data obtained through observation using the researcher as an instrument equipped with interview guides, electronic voice recorder, camera, and stationery. The informants used in this study were determined by purposive techniques, that is associated with the objectives set out in the study. In order to support the accuracy of the data, this study uses data in the form of numbers obtained from data sources, especially secondary data sources. A combination of qualitative data and numerical data is performed to conduct a holistic analysis of the research focus.

Data obtained in the field were analyzed by descriptive interpretative data analysis technique. The process of data analysis is done by classification, reduction, and interpretation. Classification of data is done by grouping the data in accordance with the needs of the analysis. Reduction of data is done by selecting, sorting, and centralizing the data according to the research needs. Interpretation of data is a process of interpreting data that has been reduced to find answers from the focus of this study. The validity of the data is tested by triangulation techniques, namely triangulation of data sources, triangulation of method, and theory triangulation.

\section{Results and Analysis}

Strengthening informal cultural ties as a vehicle for maintaining social relations between the Balinese community and the Sasak community in Mataram City there are four segments that need to be addressed, namely contacts between the Balinese community with Sasak in Lombok, the implementation of Balinese culture and Sasak culture in historical Lombok, the construction of informal cultural ties relationship between the Balinese community and the Sasak community, and the dynamic of informal cultural ties in the vortex of external influences. These four aspects are analyzed in the following sections.

\subsection{Contact between Bali-Hindu and Sasak-Islam Intercommunity in Lombok}

The contacts that occurred between Balinese communities who embraced Hinduism with the Sasak community who embraced Islam in the historic era closely linked with the expansion of the territory of the Kingdom of Bali in the historical era. The success of Karangasem Kingdom controlled Lombok became the determinant of the arrival of the Balinese in relatively large numbers to settle in Lombok. The arrival of the people of Bali to Lombok in large numbers according to Agung (1991:93) relates to efforts to break the popular resistance against the power of the Kingdom of Karangasem in Lombok. Reinforcements consisting of hundreds of families come from Karangasem Bali from month to month to Lombok. The leader of the wave of migration is mostly the family of King Karangasem, along with his relatives and friends. The Balinese who settled in Lombok during the historic period according to Parimartha (2002:37) that at least since the 17th century Balinese people and people who came from outside Lombok Island mixed with the people of Lombok.

The Balinese who settled in Lombok as followers of King Karangasem in expanding his power to build a social system, culture, and religious implementation of the religion that is similar to the system applied in the place of origin in Bali. With regard to the residence is located around the royal palace area. The settlements of Balinese who are close to the royal palace, referring to Wirawan (2016: 99) as a defense strategy against the kingdom from enemy attacks who want to overthrow the power of the Kingdom of Karangasem. The Balinese have a very high loyalty to the king because it is relied upon to strengthen the power of the Karangasem kingdom in Lombok.

The existence of the Balinese people in Lombok during the reign of the Karangasem Kingdom met with the natives of Lombok Island, namely Sasak ethnic. The power of Karangasem Kingdom was obtained through war. The people of Sasak ethnic who have been defeated, especially those who settled near the

Wirawan, I. (2018). Maintaining Social Relationship of Balinese and Sasak Ethnic Community. International Journal Of Social Sciences And Humanities (IJSSH), 2(1), 92-104. doi:10.29332/ijssh.v2n1.96 
settlements of the Balinese built a pattern of common life. Both ethnic groups continue the traditions inherited by their predecessors. At the same time, between the Balinese and the Sasak people also build social relations which in its accumulation can create an informal sociocultural system used as a tool for dealing with life's problems. The traditional social system is still practiced, although it has been experiencing a thawing in some aspects. Synergize with it, Suprapto (2013:103) asserted that at certain limits began to decrease still develop the type of bond of citizenship that is informal. The unofficial, but still effective, daily bonds can still maintain social cohesiveness among groups. Even the existence of unofficial citizenship bonds is more effective in maintaining social cohesiveness than formal and organized citizens' ties.

The relationship between the Balinese and the Sasak people during the Karangasem Kingdom was relatively good. The phenomenon is indicated by the attitude of mutual respect between them. Based on

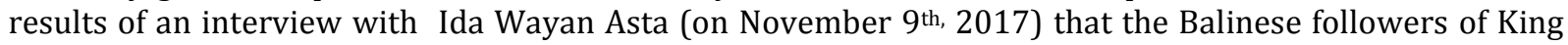
Karangasem who have succeeded in conquering Lombok while controlling the land used as agricultural land. The land ownership of the Balinese at that time was relatively large so that many Sasak people became penyakap (cultivators) agricultural land owned by the people of Bali. This phenomenon implies that between the Balinese who have relatively large agricultural land can not cultivate their own land so that it requires cultivators from the Sasak people to establish a good relationship between the two ethnic groups. The established relationships among the Balinese and Sasak peoples underpinned by the importance associated with the factors of production, in particular, the form of agricultural land became the medium for realizing the closeness between the Balinese and the Sasak people, especially in historical times.

Synergize with the above phenomena, especially those linked to the building of social relations between the Balinese and the Sasak people through the means of production factors, in particular, the cultivation of agricultural land as well as the tendency that Balinese are highly respected by the Sasak people. Based on results of an interview with I Komang Budi Arsana (on October 10 ${ }^{\text {th }}$ 2017) that there are several areas such as Karang Jangkong, Karang Sukun, Karang Kemong, the relationship of the Balinese with the Sasak people still shows respect although not many have the land that is cultivated by the Sasak people. Land owned by the Balinese is as a result of the war in the period of Karangasem Kingdom control of Lombok. The people of Bali as followers of King Karangasem when expanding power to the island of Lombok through war and managed to conquer the island of Lombok as well as control the lands that exist in the area he conquered. The impact of the event is the amount of land owned by the Balinese as a result of victory in war. The lands obtained through the outcome of the battle were further worked out by the Sasak people so that the relationship between the Balinese and the Sasak people became closer. These relationships further indicate a paternalistic relationship because the Balinese as landowners take the position of landlords as patrons, while the Sasak people as land tenants are his clients.

The close relationship between the Balinese and the Sasak people is also evident from the use of language. Based on results of an interview with I Ketut Mastra (on October 12 $2^{\text {th }}$ 2017) that the way to honor the Balinese by the Sasak people used to use a very subtle language. In the mention of identity, there is the term meran and kaji. Meran as the identity for the mention of a person with a higher status, while the kaji is the identity of the self that shows the lower position. This language as a form of homage made by the Sasak people against the Balinese people. The honor is because the Balinese status is considered higher. Meanwhile, when the Balinese chatted with the Sasak people there was a very respectful attitude made by the Sasak people to the Balinese. In the use of the greeting language, the Sasak people use the word jro and pelinggih to greet the Balinese. This is done even though the Balinese are in the lower layers, that is, as the jaba Wangsa (the lowest social layer in the Balinese system) is also called with such greeting words.

The phenomenon as described above is an indicator that shows a harmony of social relationships among the Balinese with the Sasak people. The existence of factors of production possessed by the Balinese, in particular, the form of a relatively large agricultural land given to the Sasak people to cultivate the farmland became one of the foundations in order to realize the respectful attitude done by the Sasak people towards Balinese people. At the same time, the historical dimension that positions the Balinese people as winners of war becomes the determinant of the Balinese as the ruler of the region and simultaneously establishes a higher social status than the Sasak people. This phenomenon has implications for the respect of the Balinese including in connection with this phenomenon the very subtle use of 
language by the Sasak people. These social relationships can bring about a harmonious life that overcomes differences, especially ethnic differences and religious differences.

The above conditions, associated with the Social Integration Theory, indicates a synergization that the pattern of harmonious life shown by people with ethnic and religious differences can be realized. Sasak ethnic groups with Balinese ethnic groups viewed from their ethnicity showed a difference. Synergize with that Sasak ethnic group as followers of Islam have different belief system or religion with ethnic group of Bali who embrace Hinduism. The existence of differences between the two ethnic groups is not an obstacle in realizing the life of harmony. With regard to it has been built social integration among people who have ethnic differences and at the same time have different religious beliefs. Social integration has indicated that the differences that exist in social space life can be realized social cohesiveness in order to realize togetherness in the middle of existing differences.

\subsection{Implementation of Balinese Culture and Sasak Culture in Lombok of the Historical Era}

The encounter between the Balinese and the Sasak people in Lombok during the historical period has the possibility of embodying the cultural contacts of each of the ethnic communities. The Balinese ethnic group implements a Balinese cultural system inherited from their predecessors. The cultural system which is actualized by the Balinese ethnic group is imbued with the teachings of Hinduism. In connection with that, the implementation of religion and cultural practices indicates the existence of compounding. A synergistic phenomenon also occurs among Sasak ethnic communities who implement the Sasak cultural system as a cultural heritage override to their predecessors. Sasak ethnic groups who embrace Islam also have a number of ceremonial activities related to the implementation of customs and culture. Both systems of cultural heritage of the past is still continued because it has an important meaning in improving the quality of life of supporters. Based on the results of interviews with Anak Agung Byarsah descendants of King Karangasem (on October 13 $3^{\text {th }}$ 2017) that there are a number of Balinese and Lombok cultural traditions that are held together. Even the tradition is related to the belief system, as is done in Lingsar Park in the form of a perang topat rite. This tradition has been done for a long time. Synergize with it, Koentjaraningrat (2004: 29) reveals that there are cultures that look important in human life is a long time ago. In such cultures, people will more often take guidance in the conduct of examples and events in the past.

With regard to the implementation of Balinese culture in Lombok is actually a continuation of the cultural system that has been built by the ancestors of the Balinese people. Cultural system is imbued with the teachings of Hinduism so that in cultural implementation is often difficult to separate between religion and culture. Based on results of an interview with Ida Wayan Asta (on November 9 $9^{\text {th }}$ 2017) that the implementation of Balinese culture to date is still continuously preserved its existence is closely related to the implementation of Hinduism. One example is in the art of gamelan (Balinese music instrument) that is staged at a religious ceremony shows the existence of a combination of culture with the implementation of religion. In synergy with it, based on results of an interview with I Gede Mandra (on October 19th, 2017) that in the implementation of Balinese culture that is imbued by the teachings of Hindu religion seeks to build harmony, either vertically or horizontally. In realizing the upward vertical alignment, namely Ida Sang Hyang Widhi Wasa along with his manifestations, horizontally with his fellow human beings, and downward relationships with his natural environment. In the teachings of Hinduism known as the concept of Tri Hita Karana, the three things that cause happiness. Tri Hita Karana elements consist of parhyangan, pawongan, and palemahan. Parhyangan associated with realizing harmony with Ida Sang Hyang Widhi Wasa along with his manifestation, pawongan associated with realizing harmony with fellow human beings, and palemahan is a form of harmony with the natural surroundings. Tri Hita Karana according to Wiana (2007:8-9) as a life philosophy to realize a balanced and consistent attitude of life to trust and devotion to God, to serve others, and to maintain the welfare of the natural environment. Tri Hita Karana should be understood holistically as a unified whole, synergistic, and consistent as a universal philosophy of life.

The Balinese cultural system that is imbued with the teachings of Hinduism, on the one hand, is similar to the implementation of cultural systems implemented by the Sasak ethnic group in Lombok. With regard to it, based on the result of an interview with Lalu Anggawa (on November 20th, 2016) that in the Sasak

Wirawan, I. (2018). Maintaining Social Relationship of Balinese and Sasak Ethnic Community. International Journal Of Social Sciences And Humanities (IJSSH), 2(1), 92-104. doi:10.29332/ijssh.v2n1.96 
culture there are three aspects that serve as guidelines to realize balance, harmony, and harmony of life. Related to the harmony of life concerning three relationships, that is adat gama, adat tapsila, and adat luwir gama. Adat gama involves human relationships with God, adat tapsila concerning human relations, and adat luwir gama concerning relationships with the natural environment.

Relying on the above phenomena, especially those concerning the implementation of Balinese culture imbued with the teachings of Hinduism with the implementation of the Sasak culture inherited by their predecessors is essentially a resemblance in its implementation. The resemblance is primarily concerned with attempting to realize a harmony of life which emphasizes the building of harmonious relationships, both vertically and horizontally. The upward vertical relationship in both cultural systems is essentially an effort to realize the relationship with the supernatural power as the source of all creation in the universe. Relationships that are built horizontally in accordance with the cultural concepts of the two ethnic groups above are related to harmony between people together in order to realize social cohesiveness. Downward vertical aspects that need to be built in order to realize harmony in human life is to perform actions that essentially seek to realize harmony with the natural surroundings. The existence of similarities of the core cultural implementation of each ethnic group is very open for the creation of cultural elements that can be mutually used in accordance with the needs of each ethnic group.

The cultural contact between the Balinese cultural system and the Sasak culture system has the possibility of establishing cultural integrity that has accumulated opportunities to build social closeness between the two ethnic groups. With regard to it, based on result of interview with I Made Kastawa (November 27th 2017) that there is some evidence to indicate the existence of social proximity processes between ethnic groups through cultural execution, as some Sasak ethnic societies love the implementation of Balinese culture, especially those involving seni menabuh gambelan (playing Balinese music instrument). They are very happy with the gambelan Bali. The Sasak people often beat Bali gambelan when the Balinese perform the Hindu ceremonies. In addition, in the aspect of cultural blend also occurs the use of a number of elements of Balinese dance clothes that are used to complement the Sasak dance dress. In the art gambelan Sasak, in the form of gendang below also use number of clothing mix with Balinese traditional dress. The event is related to cultural acculturation, as expressed by Bakker (1984: 115) that two cultures meet face, there is acceptance from other cultural values, new values are incorporated in the old culture.

The cultural contact that occurs, as described above, on the one hand, can bring about social solidarity among the plural society consisting of a number of differences within it. The encounter of the Balinese with the Sasak people during the historical time has implications for the cultural contact of each ethnic group and at the same time can realize the occurrence of awareness to accept the different cultural elements as complementation of the cultural system it has. One thing that is very specific in the cultural contact is the existence of elements of commonality that became the foundation for realizing harmony in life. The similarity of these elements is rooted in the cultural heritage of the past that can be used as a foundation for building awareness about the basic nature of harmony embodied, both vertically and horizontally. Establishment of social closeness based on a cultural system by each ethnic group of different religions is associated with Social Integration Theory as a phenomenon that reinforces the theory, especially the realization of integration between ethnic groups Bali-Hindu with Sasak-Moslem through the traditional cultural system. Synergize with it, Synergize with it, Khalikin (2009: 127) suggests that in the tradition of society and from the point of view of local culture, the realization of social harmony in the social order and the embodiment of sublime art and beauty norms. With it, religion becomes the vehicle for the preservation of the noblest values.

\subsection{Construction of the Informal Cultural Ties Among Societies of Bali-Hindu and Sasak-Moslem}

The construction of cultural ties between Balinese-Hindu and Sasak-Moslem as part of efforts to build social harmony has been pioneered since the historic era. Both ethnic communities recognize the importance of realizing a life based on attitudes that understand each other and accept differences within the framework of togetherness. There are a number of sociocultural systems that have been established as a medium for realizing bonds of kinship, both internally among the same ethnic group as well as externally with other ethnic groups. The following are described and analyzed on the informal cultural ties had been built by Balinese and Sasak people in order to create social harmony in their lives. There are three types of 
informal cultural ties that are focused on this research, which is related to ngejot tradition, traditions of saling undang, and majenukan tradition. These traditions become tools to connect individuals to interact with each other. Traditions that are actualized in action to connect people to each other are cultural practices. The phenomenon is correlated with the opinion Kusumohamidjojo (2009:72) that the pattern of social behavior is instrumental in producing culture. Culture gathers the realization of the human self in response to each other, but the social response was initially driven by the need to respond to nature.

a) The Ngejot Tradition

The ngejot tradition is one of the traditions that have been practiced since the historical time, both internally among the same ethnic group as well as externally with other ethnic groups. Among the same ethnic groups, this ngejot tradition is carried out by Balinese with fellow Balinese citizens, as well as among the Sasak people ngejot with fellow citizens of the Sasak people. Based on the result of an interview with I Gde Tapak (September 13 ${ }^{\text {th }}$ 2017) that ngejot tradition is performed on ceremonial occasions, both traditional ceremonies, and religious ceremonies. Implementation of tradition ngejot in the implementation of customs among the people of Bali is almost identical to the implementation of Hinduism. This is because in the implementation of Hinduism the customary and cultural dimension plays a very important role and as if between customs, culture, and religion has built communication. The close relation between Hindu religious teaching with Balinese culture according to Patera (2008:45) because Hindu religion animating Balinese culture. The enforcement of Hinduism has an impact on the implementation of Balinese culture.

Implementation of the ngejot tradition among different ethnic groups, especially those done by Balinese people and Sasak people in the past is a tradition that is done during religious holidays. The ngejot tradition carried out by the Balinese people with the Sasak people to date is still preserved, especially in Balinese people who still have rice fields cultivated by the Sasak people. Ngejot tradition in the implementation of Hinduism given to the semeton (relatives) Sasak on penampahan galungan holiday. The opposite is done by Sasak people on the implementation of Islam holiday, such as lebaran, they do tradition ngejot to their relatives the Balinese people. The ngejot tradition of the BalineseHindu belief system has an important significance for building a harmony of life as the implementation of yajña teachings. In synergy with it, Wiana (2004:21) reveals that awareness of doing yajña must be done to all living things to produce religious culture.

The ngejot tradition described above is an implementation of a sociocultural system conducted by the Balinese people with the Sasak people who have done since the historical time. The existence of the ngejot tradition implemented by the two ethnic groups above implies the existence of established social relationships between ethnic Balinese groups who embraced Hinduism with the Sasak ethnic group who embraced Islam. Although the two ethnic groups embrace different religions, in the execution of the religious festivals of each ethnic group still pay attention to the attention to give jotan (food or beverage) to their relatives who did not celebrate the religious holiday. This ngejot tradition, especially done by those who have social relationships, both family relationships, and relationships that are as an emotional closeness.

The above phenomenon as an indicator that in the life of society with a relatively high level of plurality, especially among the people of Bali-Hindu and Sasak-Moslem can bring great attention to their relatives by giving jotan on the religious holidays owned by each ethnic group. The ngejot tradition between the Balinese and the Sasak people was at the time of the feast. The Balinese if celebrating galungan holiday provide jars of food or beverage to the Sasak people. Likewise, the Sasak people who carry out the day of idul fitri (the holiday of Islam) give jotan to their relatives, especially the people of Bali. This tradition is very common in the past. The implicit meaning behind the symbol of the jotan is the form of homage given by one ethnic group to the other ethnic group in relation to the implementation of religion held by each ethnic group. Ngejot tradition loaded with symbols that contain meaning as improvement of the quality of life, either individually or collectively. Synergized with it, Van Paursen (1988:227) insists that humans interpret his world through symbols even through all his activities in the field of culture. Even when humans think that they are dealing with "objective nature," humans have interpreted the realm, even evaluated it.

Wirawan, I. (2018). Maintaining Social Relationship of Balinese and Sasak Ethnic Community. International Journal Of Social Sciences And Humanities (IJSSH), 2(1), 92-104. doi:10.29332/ijssh.v2n1.96 
b) The Tradition of Saling Undang

The saling undang tradition is one form of cultural ties that informally occur among the ethnic Balinese community who embraced Hinduism with the Sasak ethnic community who embraced Islam since historic time. The inviting tradition of the Sasak people is called pesilak tradition. This tradition is actualized by inviting relatives to help complete relatively large-scale activities in the family environment. Besides aiming to help accomplish the work there is a meaning embodied in the tradition of saling undang, namely establishing the bond of brotherhood between those who invite and the invited. This phenomenon indicates an effort to build a life of mutual respect, both internally in the same ethnic group as well as externally with different ethnicities.

The tradition of saling undang, according to I Gede Tapak based on the result of the interview (on September 13 ${ }^{\text {th }}$ 2017) who was stated that before the 1970s between the Balinese with the Sasak people is usually done if have a celebration. The Balinese invited by the Sasak people should eat as a form of homage. Likewise, the Balinese who have celebrations invite the Sasak people. If the invited Sasak people are supplied with special ingredients, such as buffaloes, cows that later they work on their own cooking. Likewise determining the day to bring the invitation is distinguished by the invitation of the Balinese. The existence of religious differences between the two ethnic groups is not an obstacle in the process of implementation of the tradition.

One thing that is very important in the implementation of these traditions is the existence of attitudes of mutual respect when doing activities tradition of saling undang. The Balinese are usually in the celebration activities using meat, in the form of pigs. Meanwhile, the Sasak people did not consume pork according to the teachings taught in Islam. In relation to that, when the Balinese have a celebration that happens to invite their relatives to the Sasak people who are Muslims, then there is a special day to bring in the Sasak people and include the materials that are also provided specifically so as not to mix with the materials used by Balinese people.

Based on the above conditions, among the Sasak people who carry out religious events, such as maulid also invites the Balinese in order to enliven the religious activities. In addition to religious events tradition of saling undang is also done at the wedding ceremony. This shows that between the Balinese and the Sasak people have relatively strong family ties. The tradition of mutual law in order to participate in enlivening the activities undertaken by their relatives implies that although they are different ethnic and at the same time different religions are not a constraint in realizing social bonds. The tradition of saling undang that is closely related to cultural practices carried out by one ethnic group and included in enlivening activities associated with the implementation of religion is very positive in order to realize a harmonious social life. Differences that exist between them are accepted and used as a medium for coloring togetherness in the middle of a pluralistic frame.

c) The Majenukan Tradition

The majenukan tradition is also one of the means to establish the kinship ties between Balinese who embraced Hinduism with the Sasak people who embraced Islam. The tradition is actualized when people die in one of the ethnic groups. The grand tradition is carried out, both internally among the same ethnic group as well as externally with different ethnic groups. The majenukan tradition has been established since the historic period and until now there is also done. The important thing is there is information to invite. Even giving information to invite is currently done through a mobile phone. Based on the result of an interview with Ida Wayan Asta (on November 9th, 2017) that tradition of mejenukan among the Balinese usually at the ceremony on three days after death, but the Sasak people at nyiwaq ceremony his name is on the ninth day after the ceremony died. Indeed, until now the tradition of mejenukan still done between the people of Bali with the Sasak people. The grand tradition has been historic in realizing the social closeness between the Balinese who embraced Hinduism and the Sasak who embraced Islam. In the implementation of tradition majenukan which is done today is important is the delivery or communication so that the news can be mutually sustainable. The existence of information technology devices, such as cellular phones makes it easier to convey information to other parties, especially their relatives. By using these technologies, the faster the process in the delivery of information relating to the tradition of majenukan itself. 
Basically, the tradition of majenukan described above implies that since the historic periods of the ethnic groups of Bali and Sasak have practiced the tradition. Individual ethnic groups who happen to have family died to deliver the sad news to fellow ethnic groups and including with other ethnic groups who became his relatives. The majenukan tradition begins to be preserved for long periods of time. The core of majenukan tradition is no other is the awareness of each individual or group to feel the condolence when one of the families there who died. The bond that is built through this majenukan tradition is an informal, informal form of bonding, but it has a very important role in building the emotional bond between them. Based on the result of an interview with I Gede Mandra (October 19th, 2017) these emotional bonds can be positioned as embodying social bonds between individuals, whether within the internal environment of the same ethnicity or externally with those of different ethnicities.

The informal cultural ties described above have a very important meaning in building social unity between Balinese-Hindu society and Sasak-Moslem society. The informal cultural ties in the form of ngejot tradition, the tradition of saling undang, and majenukan tradition that had been built in a historical time if properly implemented in everyday life can achieve social harmony. Despite its informal evens, but having an effective social energy can realize the consciousness to live together in harmony. Synergizing with that, Suprapto (2013: 205) emphasizes that the patterns of civic engagement bonds that take place unofficially or quotidian ties as termed proved to be able to build or become a bridge connecting different communities of ethnicity and religion in the city of Mataram.

\section{Conclusion}

The above explanation has outlined the existence of cultural ties of informal cultural ties that have a very important role in maintaining social relations between Balinese ethnic and Sasak ethnic groups in the city of Mataram. The informal cultural ties, despite the unofficial nature that has been built since the historic time, have the social energy to melt the boundaries of the differences between the two ethnic groups. The cultural ties of quotidians that embody the meaning of social unity in the framework of togetherness if they can be preserved can preserve social harmony amid the plurality of social life. The most important issue in order to preserve the existence of the quotidian cultural ties is the influx of external influences, particularly the potential modernization imprint to disperse them.

The occurrence of decommissioning in the execution of noble traditions, particularly those relating to the cultural ties of quotidian that are implemented in the tradition of ngejot, the tradition of saling undang, and the majenukan tradition among the Balinese-Hindu and Sasak-Moslem communities, as above implies a reduction in the implementation of cultural traditions past. This phenomenon indicates the happening of social intertwining that has been built since the historic era. Dynamics and changing times become determinants in preserving past cultural traditions to future generations. The importance of the values implicit in past traditions that can build social unity between the Balinese-Hindu ethnic community and the Sasak-Moslem ethnic community would need to be revitalized to the noble cultural heritage. Past traditions that have built informal cultural ties between the two ethnic have important meanings for the maintenance of social harmony, especially in the midst of a profound external influence that tends to disperse the cultural heritage of the past.

\section{Acknowledgments}

The author would like to thank the chairman of Mataram State Hindu College of Gde Pudja on support costs given for doing this research. At this moment I also like to thank lecturers and staffs who provided encouragement to this research can be completed. The author expressed his appreciation to the field workers with the indomitable spirit assist in the retrieval process research data. As well as the author would like to thank the people at the Bayan subdistrict, especially the informants with sincerity to provide information as research data. Special thanks to Jro Mangku Made Griya Pasek (as figure Hindus), Mangku Arsyana (traditional leaders Sasak in Masjid Bayan Beleq), Ayu Kartini (as chairman of the art galleries), Raden Sembali (as artists performing arts), and other informants for their assistance in providing information as research data.Thanks also authors say to all those who can not be mentioned one by one who helped in the research process. Hopefully, this is useful for readers.

Wirawan, I. (2018). Maintaining Social Relationship of Balinese and Sasak Ethnic Community. International Journal Of Social Sciences And Humanities (IJSSH), 2(1), 92-104. doi:10.29332/ijssh.v2n1.96 


\section{References}

1. Agung, A. A. K. (1991). Кupu-kupu kuning yang terbang di Selat Lombok: lintasan sejarah Kerajaan Karangasem, 1661-1950. Upada Sastra.

View in (Google Scholar)

2. Bakker, J. W. M. (1984). Pustaka Filsafat FILSAFAT KEBUDAYAAN, Sebuah Pengantar. Kanisius. View in (Google Scholar)

3. Fontana, A., \& Frey, J. H. (2009). Wawancara Seni Ilmu Pengetahuan. Dalam Denzin, Norman K dan Yvonna S. Lincoln.

View in (Google Scholar)

4. Ahmad, H. H. A. WADAH KERUKUNAN.

View in (Google Scholar)

5. Koentjaraningrat. (1974). Kebudayaan, mentalitet, dan pembangunan: bungarampai. Gramedia. View in (Google Scholar)

6. Kusumohamidjojo, B., \& Jamilah, S. (2009). Filsafat kebudayaan: proses realisasi manusia. Jalasutra. View in (Google Scholar)

7. Parimartha, I. G. (1995). Perdagangan dan politik di Nusa Tanggara 1815-1915. View in (Google Scholar)

8. Rema, N. (2018). Arca Ganeśa dalam Sikap Swastikàsana. Berkala Arkeologi SANGKHAKALA, 17(2), 155168.

View in (Google Scholar)

9. Ridho, M. (2017). Inter-Religious Relationship Between Hindus and Muslims in Lombok. harmoni, 16(1), 38-56.

View in (Google Scholar)

10.van Peursen, C. A., \& Hartoko, D. (1976). Strategi kebudayaan. Penerbitan Kanisius. View in (Google Scholar)

11.Varshney, A. (2003). Ethnic conflict and civic life: Hindus and Muslims in India. Yale University Press. View in (Google Scholar)

12. Wiana, K. (2004). Mengapa Bali Disebut Bali. Paramita.

View in (Google Scholar)

13. Wiana, I. K. (2007). Tri Hita Karana Menurut Konsep Hindu. Surabaya: Paramita. View in (Google Scholar)

14.Sigit, P., Soetomo, S., Syahbana, J. A., \& Manaf, A. (2015). Ruang Netral di Kota Ambon (Segregasi dan Integrasi Ruang Kota).

View in (Google Scholar)

15. Sigit, P., Soetomo, S., Syahbana, J. A., \& Manaf, A. (2015). Ruang Netral di Kota Ambon (Segregasi dan Integrasi Ruang Kota).

View in (Google Scholar) 
16.Suryasa, I. W. (2016). Potential and actual expression in blocking system (morphology studies). International Journal of Research in Social Sciences, 6(3), 682-691.

View in (Google Scholar)

17. Mardika, I. N. (2017). Opposition of Community Citizenship Against the Policy of the Village's Leader. International Journal of Social Sciences and Humanities (IJSSH), 1(3), 74-87.

View in (Google Scholar)

18. Pemayun, A. G. P., \& Maheswari, A. I. A. (2017). Economic Impacts of Craftsman Statue on Community Based Tourism Development. International Journal of Social Sciences and Humanities (IJSSH), 1(3), 59-73.

View in (Google Scholar)

Wirawan, I. (2018). Maintaining Social Relationship of Balinese and Sasak Ethnic Community. International Journal Of Social Sciences And Humanities (IJSSH), 2(1), 92-104. doi:10.29332/ijssh.v2n1.96 


\section{Biography of Author}

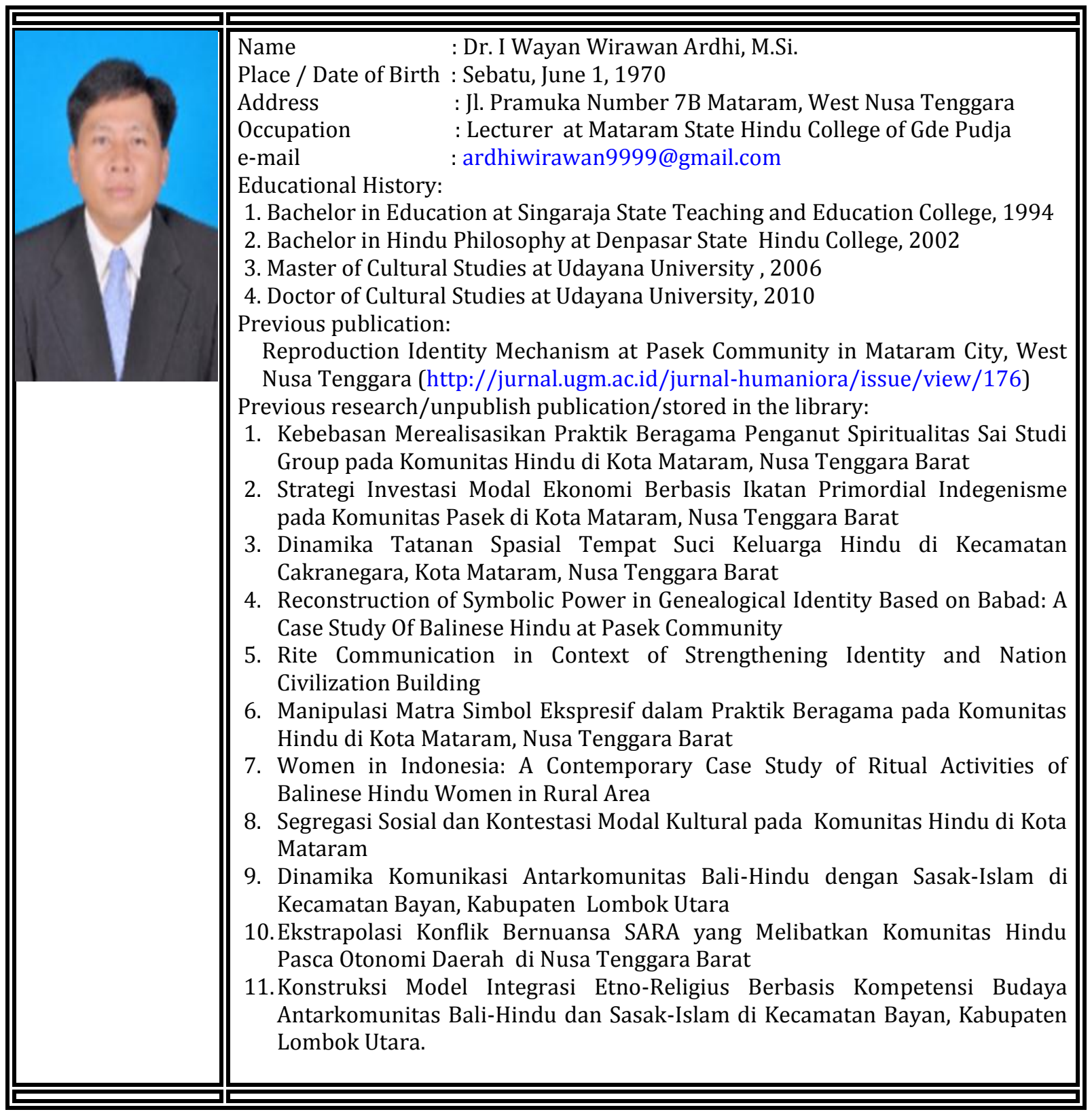

